\title{
Mission as the creation of a God-ward culture: A critical missiological analysis
}

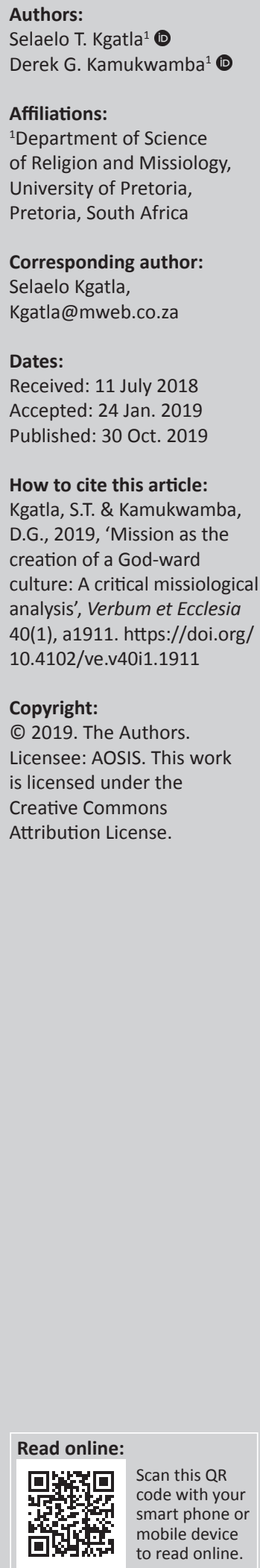

The traditional definition of 'mission' has always carried with it the salvation or redemption connotation, leading to the division of the world into two spheres: the world for the saved and the world for the unsaved. Thus, when the term 'mission' is used, it is primarily understood as the geographical extension of the Christian faith; it is understood as the planting of the church and the conversion of non-Christians to the Christian faith. The term still carries the concept of the geographical movement of the Christian faith, the crossing of seas from the 'developed world' to the 'non-developed world', such as Africa, Asia, Latin America and West Indies. While people have moved on from seeing mission as the crossing of seas or geographical boundaries, there still lingers the concept of the crossing of cultural boundaries or barriers. This article proposes the concept of mission as the creation of a Godward culture, the creation of a God-ward cultured community or communities as God's mandate to humanity. This concept acknowledges culture as a gift from God to humanity and that no two cultures can be identical as each culture is unique. This means that no one culture can be said to be a Christian culture, neither can names from one culture or region be said to be Christian names. The article tackles the subject matter by defining the term 'culture', differentiating the God-ward cultured community from Christendom and by considering God's mandate to humanity.

Intradisciplinary and/or interdisciplinary implications: The article critiques the traditional understanding of Christian mission and proposes the concept of mission as the creation of a God-ward culture - that is, creation of a God-ward cultured community or communities as God's mandate to humanity. It contributes to missiological, ecclesiology, church history and practical theology. The article provides new insights into the holistic understanding of God's mission to the world.

Keywords: Christendom; culture; mandate; mission; kingdom of God; missionary; developed world; community; creation; salvation.

\section{Christendom and culture}

In the traditional understanding of God's mission, the idea of geographical expansion of the Christian faith, church planting and the conversion of non-Christians to the Christian faith predominates (Goheen 2014:15). This understanding of mission in the developed world from the 16th century onwards led to the promotion of Christendom. ${ }^{1}$ Tennent (2010) defines Christendom as:

A political and ecclesiastical arrangement that reinforces a special relationship between the church and the state. The state strengthens the church by promoting the Christian hegemony over the religious and cultural life. The church, in turn, gives legitimacy to the state by supporting the political establishment and tacitly granting divine sanction to the actions of the state. (p. 18)

Tennent further explains that Christendom can exist in an official, legally binding way or in an unofficial but explicit way with the constitution granting Christianity special status and in an unofficial implicit form, which is more in expression rather than in the constitution. When it exists in an official form, the church receives protection and many privileges from the civil authorities in that it is the established religion of the state (Tennent 2010). Through the concept of Christendom, Christianity dominated the world, thereby dividing the world into two spheres: the 'Christian' world and the pagan or heathen world (Hillerbrand 2007). Geographical boundaries were drawn. Christendom represented the 'Christian' world and all those outside Christendom boundaries

1.By Christendom, I mean Christians considered as a group and the portion of the world in which Christianity is the dominant religion or the collective body of Christians a kingdom. There is usually a very thin line dividing the church leadership and civic leadership in the concept of Christendom. This understanding was carried by missionaries in many instances who focused on the conversion of leaders or rulers of communities. 
were regarded as the lost with belonging to the realm of darkness (Stott 1975:25-26). They were in the pagan world (Bosch 1982:2-10).

As culture is at the centre of every society, this understanding meant that all non-Western cultures were to be converted. Only the Western culture was to be regarded as the Christian culture and only Western names were regarded as Christian names. It was through this conceptual framework that Christianity was exported to countries outside of Europe and America.

What does the term 'culture' mean and how is it used in this article? The term 'culture' in English is derived from the Latin verb colere, which means to cultivate or to instruct, and the noun cultus is the word for cultivation or training (Tennent 2010:169). This means that culture has to do with cultivation or training and because culture has to do with training and learning, it cannot be inherited. Thus, when a child is born, that child is cultureless as culture ${ }^{2}$ is something that he or she will have to learn as he or she develops, mostly through association. Burnett (1996) defines culture as 'the total way of life of a particular people' as he explains that:

Culture has most simply been defined as the total way of life of a particular people. It includes the outward practical aspects of how people obtain their food, how they dress, how they organise their society and marriage, as well as how they practise their religion or what music they play. Culture also includes the language and religious beliefs of the society, both which have great influence in forming the ideas of the people. At the core of any culture are those fundamental ideas that are usually called the 'worldview' of the society and enable the people to make sense and order of their environment. (p. 14)

Christendom sees Christianity at the centre of culture (Burnett 1996). Bosch (1982:4) makes a pertinent point that it is with this understanding that Western culture(s) came to be regarded as the Christian culture(s), while non-Western cultures were all regarded as pagan cultures.

For instance, missionaries to Africa regarded all the names from their country of origin as 'Christian names', while all the African names were regarded as pagan names. Because of this, everyone desiring to be baptised could not be baptised with their local African name (Tennent 2010:21-22). African names could not in any way be baptism names and one needed to change one's name and only then could he or she be baptised, as Kimeria observes (Kimeria 2017).

The assumption was (and still is in some circles) that the developed world, Western cultures and Western names are shaped by the gospel, and thus everything and everyone from those Western boundaries are 'Christians'. In the boundaries

2.Culture is a way of life that a particular group of people or community develops in accordance with the environment under which that particular group of people lives. accordance with the environment under which that particular group of people lives. It is shaped by experience, history and language. Because of the differences in experiences, languages, history and living environment, no two cultures can be identical. There may be some similarities but they cannot be identical. Each culture is exceptional and unique. It is also worth noting that because environment and experiences keep on changing, culture does not remain static; it also changes. As the community develops, culture is also reshaped and redefined. of the non-developed world, cultures and names were not yet under the sway of the Christian hegemony and so no one and nothing from there could be said to be Christian (Tennent 2010:21-22).

Mission was conceived of as coming from the developed world to the pagan world or the non-developed world. This meant that mission could only be carried out in the nondeveloped world, in the pagan world and to non-Western persons. That which is being performed in the developed world and to Western persons was not mission but ministry (Yoder 2014:38). The concept of 'here' is a culture shaped by the gospel, and therefore here people are all Christians, and 'out there' are cultures not yet shaped by the gospel and so all who are out there are non-Christians. This is the understanding under which missionary societies were founded. The main task of these missionary societies was to send missionary personnel to the non-developed world and to the lost pagans. While commenting on being lost, Yoder (2014) has this to say:

But, what does 'lost pagan' mean? The missionaries defined salvation in terms of European semantics, European experience and European concepts of what it means to be human, to be saved and therefore to be lost. (p. 38)

This understanding shaped and defined the way missionaries who took Christianity to the non-developed world operated. For them, the world was firmly divided into two: the world for Christians and the world for non-Christians. They operated distinctively and independently. Those who came for ministry had the diocesan office as their centre of operation, while those who came for mission had 'mission stations' on the mission fields as their centre for operations. When Yoder comments on being independent, he has this to say (Yoder 2014):

In European Christianity, the agencies that carried out the sending out process were not the church. The church was a sociological agency responsible for governing pastors and placing them in pulpits and handling the denomination's eternal affairs in any given country. The organisations that sent missionaries were missionary societies that were created spontaneously by voluntary membership who then created their own structures. A theologian in a European Protestant university (or an American Ivy League university) did not feel that the missionary enterprise was something for which his/her church was responsible. Theology had to do with domestic church management. (p. 37)

For example, Anglicans who started the Anglican Church in Zambia came as two distinctive groups: those who came to the lost Africans and those who came for the Christian Western settlers (The Church of England Archbishops' Committee of Enquiry on the Evangelistic Work of the Church 1918). Those who came for the lost Africans came as missionaries and were directly under the missionary society, the Universities' Mission to Central Africa (UMCA), while those who came for the 'Christian' Western settlers working as farmers, railway workers, miners, colonial administrators 
and civil servants came as chaplains and were under the diocese. Missionaries settled in the rural areas away from urban areas, while chaplains settled in urban areas. The rural part of the country where Africans had their permanent homes was considered the mission field, and the centre from which missionaries operated was called a 'mission station'. ${ }^{3}$ Urban areas were not considered to be mission fields; thus, centres from which chaplains operated were not mission stations but 'parishes'. In urban areas, Africans were visitors and non-citizens and to live and work there they needed to have passes. Western settlers were the citizens of urban areas, and therefore they did not need a pass to live, work or be there.

\section{The concept of a God-ward culture}

What does it mean to speak about a community or communities with a God-ward culture? Speaking about a God-ward cultured community is not the same as speaking about Christendom. This article is not advocating for another form of Christendom nor is it advocating for a world of a monoculture but for the creation of God-ward cultured communities. We have noted that culture is a way of life that a particular group of people develops in accordance with the environment under which that particular group of people lives. AGod-ward culture implies a culture that acknowledges God as the source and final purpose of creation.

The concept of mission as the creation of a God-ward culture does not aim to promote one particular culture as the 'Christian culture', thereby exporting or importing that particular culture to all corners of the world where the gospel of Christ has been received. Unlike the concept of Christendom, which dominated culture, the concept of a God-ward culture acknowledges culture as a gift ${ }^{4}$ from God, potentially given for the well-being and identity of every community.

It acknowledges that culture is potentially good and that there can be no community without a culture. For reason, no one culture should be declared or regarded as 'the Christian culture', thereby exalting that particular culture above other cultures. No name should be declared or regarded as 'the Christian name', thereby exalting that particular name or those particular names above other names. Names are names and in themselves, they are not a source of blessing or curse, belief or unbelief. Each culture has names that identify an

\footnotetext{
3.The concept of a 'mission station' has its roots in the understanding that the mission field is in absolute darkness and in a state of lostness: lost in knowledge, lost in field is in absolute darkness and in a state of lostness: lost in knowledge, lost in
culture, lost in development and lost in everything. In the midst of this darkness and lostness, the mission station comes in as the only source of light, more like the lighthouse. It is because of this understanding that a 'parishes' in urban areas or back home in the developed world, despite doing the same work as that in a nondeveloped world setting, was not referred to as a mission station. The mission station was the lighthouse for missionary work among the primitive people of the non-developed world.

4.Genesis 11 (Tower of Babel) is seen as the introduction of 'the world cultures'. Here, we see a community which is concerned with leading a life of their own without God. It seeks to be independent from God and attempts to create its own kingdom (Gn 11:1-4), not wanting to obey God's command: 'And you, be fruitful and multiply, bring forth abundantly on the earth and multiply in it' (Gn 9:7). God introduces many languages as a tool for preventing humanity from creating its own kingdom (Gn 11:6-9). As Babel is acknowledged to be the introduction of "world cultures" then culture is God's gift to humanity because the introduction of many languages was God's initiative.
}

individual in that particular culture, or tell a story of the happenings in a family or in that particular group of people. Nearly in all cultures, the name identifies and locates the bearer of the name in a particular family or group of people. It is with this understanding in mind that Elizabeth's neighbours and family members could not understand her when she refused to name her son after his father Zechariah (Lk 1:57-63).

Names are not simply picked at random. Africans, for example, make diligent enquiry to find the right names within the family to name their children. Sickness or misfortune may be attributed to giving a child a wrong name and in such a case, further enquiry is made and another name is selected. Europeans also name their children after parents, grandparents and friends. In most cases, it is assumed that in some mystical way, the identity or the character of the name bearer is transferred to the child; thus, it is traditionally held that names contain the person whose name is spoken. They do more than represent the person; they are the person. Names tell the story of the family and they are there to identify and locate the newly born child in the family. Thus, by demanding that people change their names, missionaries dislocated people from their local communities and placed them in the communities where the missionaries came from, in a foreign land. What was behind the missionaries' actions, knowingly or unknowingly, was the reinforcement of the Christendom.

What then does it mean to speak about a God-ward cultured community or communities? In Genesis 1:26-28, we find God's purpose for creation: his purpose is to usher in his kingdom. Bowen observes when drawing his concluding comments on the definition of the term 'mission' that 'therefore, how we define mission is less important than how we put it into practice as we relate to God and to our fellow human beings' (Bowen 2007:72). In Genesis 2:8-9 and $15-25$, we see God is demonstrating his purpose. He creates a garden and he puts humans in the garden with the kingdom environment, a kind of Eden kingdom where they are to 'live as God's people in God's land, under God's rule, enjoying God's blessings' (Roberts 2004:21). It is in this garden that he expected human beings to create a community with a God-ward culture, a community that would reflect all the attributes of God and a community that shows and tells the story of who God is. As human beings are created in the image of God (Gn 1:26), they are to represent God within the created order. They have a special role that is assigned to them; they are different from the rest of the creatures. Thus, by creating human beings in his image, God installed the human species as his image in his creation, thereby giving the human species the authority to proclaim God's sovereignty over creation. Unlike images and statues of kings and emperors in ancient world whose authority was merely symbolic, humans were authorised in a practical way to exercise authority over creation (Gn 1:26, 2:19-20). 


\section{Cultural mandate}

A cultural mandate, also referred to as a 'creation mandate', is the command or the instruction God gave to humankind through Adam and Eve as found in Genesis 1:28 and 2:15. Here, Adam and Eve, as those created in God's image, are called to exercise dominion over the whole creation and to subdue and develop it. They stand in as representatives of the human race. This call is reaffirmed in the mandate to Noah and his sons in Genesis 9:1; again Noah is seen as the representative of the human race and the whole of God's creation.

In the creation story, we see God's purpose for creation. The story begins with a powerful signal: 'In the beginning God created the heavens and the earth' (Gn 1:1). These introductory words are an affirmation of what God's place in creation is. He is the one who created; the whole creation owes its existence to God. It is God who initiated creation and he is the one who sustains creation. The words are a reminder of the authority of God as a creator. In these words, God sets the boundary which none of the creatures should cross. In these words, God is also sending a message that he is to be known through his creation. In other words, creation reveals who God is, and humans as part of God's creation were created specifically for that purpose, as Fubara-Manuel (2007) observes:

\footnotetext{
In bearing God's own image and likeness, humankind was to be the crown of creation, the deputy of God on earth, the one to make God manifest on earth, the bearer of the tokens of the divine, and the emblem of God to creation. As there was no way anyone would have been able, or will be able even today, to know God without God's own self-revelation, God chose to use humankind as the medium through which God would reveal himself to creation. The creation of the plants and animals, of the rivers and the skies, and of all other things in creation was designed by God in such a way that it is by the knowledge of humankind that these things may reflect who or what God is like. (pp. 23-24)
}

What then was the mandate to Adam? God's plan was to create earth as his kingdom and human race was made to rule over the earth as God's viceroy. In Genesis 2, we have God planting a garden as a pattern of his desired kingdom and he puts humans in charge (Gn 2:15). Humans are given kingly authority over the whole of God's creation: 'God created a good earth, a beautiful garden-kingdom, and in his goodness he entrusted it to man to care for [...] enjoy and rule as king' (McKay 1994:19). The mandate given to Adam at creation was to populate and civilise the earth, thereby developing a community with a God-ward culture. This mandate involved the whole realm of human culture and human relationship with the whole created order (Gn 1:28, 2:15) as Glasser (2003) observes:

The first obligation that God placed on Adam and Eve made explicit certain activities already built into their essence as human beings. These activities primarily embraced their social existence: marriage (completing humanity and procreating), work (subduing, tilling, guarding), and government (ruling).
God's keywords are: 'rule over,' 'work ... and take care of,' and 'name' the creatures (Genesis 1:26-27; 2:15, (18-25). These commands mark the beginning of a stream of obligation: a mandate for family and community, law and order, culture and civilisation, and ecological concern that widens and deepens as it courses through scripture. By it God calls all who bear his image to the role of vice-regents over this world, to participate responsibly in this task. (p. 38)

Peters (1972) goes further in explaining that the mandate:

$[I] \mathrm{n}$ its widest sense includes religion. It serves man in his need as socio-religio-culture creature. It includes the nature and social aspect of man such as habitat, agriculture, industrialisation, commerce, politics, social and moral order, academic and scientific advancement, health, education and physical care. In simple words, it is the qualitative and quantitative improvement of culture on the basis of the revelation therein manifested in creation. Such culture was to benefit man and glorify God. The Bible expresses it in the following terms: to populate, to subjugate, to dominate, to cultivate and to preserve (Gn 1:28, 2:15). (p. 166)

According to Peters, what we have in the Genesis creation story on this matter are 'the basic concepts and directives for an ordered and progressive society based on principles of sound morality and ethical monotheism' (Peters 1972:166). This means that humanity has a responsibility to build a 'wholesome culture' in which man can live as a true human being according to the order and creative purpose of God (Kösterberger \& O’ Brien 2001:251).

Bruce Riley Ashford and David Nelson put it this way (Ashford 2011):

Humanity has a unique role to play in God's kingdom. They are to participate in the fulfilment of God's creation by being faithful to, multiplying and filling the whole earth. To fill the whole world with his image bearers who know him, trust him, depend on him was and is the mission of Gods in creation. God seeks to be glorified in the culture mandate. Humanity is to order God's creation. We are to take what God created and use it for the purpose God ordained. These are the basics of culture, taking the resources that God gives and using them. God intended that all things would operate under his rule and his purpose. His will was for there to be a God-ward culture(s). (p. 30)

How are we to understand the cultural mandate at creation before the fall and after the fall? Defining culture as 'the total way of life for a particular group of people' means that at creation there was no culture. Adam and Eve had just been called into existence, they had just been born, they had not yet learnt any way of life, and thus the earth or the world was cultureless. God's mandate to Adam and Eve was for them to develop a culture in the cultureless world, a culture that defines humanity's place and role in God's created world and before God himself, a culture that defines human's relationship with God, human as vice-regent of God, a culture that defines human's relationship with other human being (Gn 3:9, 4:9) and a culture that defines human relationship with the environment (Gn 2:15). Instead of developing a God-ward culture, Adam and Eve through their disobedience set humanity on a course of developing 
a culture that was contrary to the initial mandate, a culture that brought on humanity and the whole creation terrible consequences, and a culture with a series of curses as seen from Genesis 3:14-19. Humans developed a culture that was focused on serving self-interests (Gn 11:3-4).

\section{Salvation mandate and mission of God}

After the failure of Adam, the whole human race was drawn into the kingdom of darkness, embracing death as God had told them: 'for in the day that you eat of it you shall die'. As Paul observes, 'Therefore as sin came into the world through one man and death through sin, and so death spread to all men because all men sinned' (Rm 5:12). But God did not give up his plan for his creation. He decided to continue his plans for developing his kingdom, where 'all is very good' (Gn 1:31). God still intended to create a world where all of creation would exist in perfect harmony and live in fellowship with God and with one another, a world where all things, the whole created order, would fit in accordingly. This world would reflect all the attributes of God, with God in total control, and with humans as God's image bearers.

As Adam and Eve failed to live up to the divine call, God decided to start afresh. Abraham is called the 'second Adam' ${ }^{5}$ and participated in God's mission of creating a community with a God-ward culture that would bring about God's blessing to the nations (Gn 12:1-2).

The Bible is God's revelation to humans concerning the whole of God's creation. It reveals his plan to his people. Thus, the whole Bible is the story of how God revealed his plan. In this plan, there are three central figures: Adam, Abraham and Jesus. It begins with Adam who through his disobedience changes the course of creation; it then comes to Abraham who through his obedience sets humankind and creation back on the course of faith, obedience and loyalty; and finally it comes to Jesus who also through his obedience, death and resurrection brings it into disclosure and fulfilment.

In many biblical writings, scholars have referred to Jesus as the second Adam and this has become an accepted norm. In this article, I have identified Jesus as the third Adam, the last of the Adams, with Abraham as the second Adam. I have taken this stance based on the basic structure of the biblical narrative and the divisions of the Bible that scholars have come up with: creation, fall, redemption and consummation

5.The term 'Adam', as the New Dictionary of Theology explains, is the Hebrew word for human or humankind (Ferguson \& Bright 1988:3). The term is used in the Bible to signify the first humans: Adam and Eve. Thus, the name Adam signifies the first to come. It is with this understanding in mind that Paul uses the term in 1 Corinthian 15:22-23 for Jesus as the first fruit of the resurrection from the dead. Adam as the first human is a central figure in God's creation; he is the ancestor of all human beings. To borrow Paul's words as used for Jesus in 1 Corinthians 15:22-23, Adam can be said to be the first fruit of God's creation. In Salvation history, the figure of Abraham is also central. Even though Paul does not call him an Adam, in the same Abraham is also central. Even though Paul does not call him an Adam, in the same way that he does for Jesus, he refers to Abraham as the father of all the faithful (Rm $4: 16)$. From this point of view, Abraham can be said to be the first fruit of the faithful in the same way as Adam is the first fruit of creation and Jesus is the first fruit of the resurrection. Looking at the name Adam as the first fruit, the first to come in time, we have Adam as the first to come in God's creation; Abraham as the first to come in God's mission of faith, obedience and loyalty; and Jesus as the first to come in the resurrection of the dead. Here, we have the concept of the three Adams. or new creation. Different scholars call the divisions by different names. Christopher J.H. Wright calls it 'The Biblical Storyline' (Wright 2010:39), Bruce R. Ashford calls it 'The Major Plot Movement' (Ashford 2011:6), Kevin De Young and Greg Gilbert call it 'The Four Broad Acts' (De Young \& Gilbert 2011:67), Simon J. Taylor calls it 'The Six Play Acts' (Taylor 2015:26-40), Graig G. Bartholomew and Michael W. Goheen call it 'The Grand Story' (Bartholomew \& Goheen 2014:17) and Vaughan Roberts calls it 'The Story line of the Bible' (Roberts 2004).

Roberts brings this out clearly in his divisions of the Bible. He divides the Bible into eight sections and relates each of the sections to the kingdom. The Old Testament has five sections. Section 1 falls in the Creation part of the grand narrative, and he calls this 'the pattern of the kingdom'. Section 2, which is the Fall, he calls 'the perished kingdom'. These first two sections belong to Adam's generation, or the 'the new beginning'. The next three sections belong to Abraham's generation and all these fall in the Old Testament part of the Redemption, under 'the second beginning', and the call of Abraham. He calls these 'the promised kingdom', 'the partial kingdom' and 'the prophesied kingdom'. The New Testament has three sections: the first two are in the Redemption period of biblical history under 'the third beginning', that is, the Jesus generation, and he calls these 'the present kingdom' and 'the proclaimed kingdom'. The last section falls in the New Creation or Consummation section (Roberts 2002:22).

Gerald. H. Anderson (1982:81) observes that 'when Christ on the cross said it is finished', he meant the whole plan that God put into operation with Abraham was completed. Roberts (2002) agrees with this observation as he explains:

God calls Abraham and makes some unconditional promises to him. Through Abraham's descendants he will re-establish his kingdom. They will be his people, living in his land and enjoying his blessing, and through them all peoples on earth will be blessed. That promise is the gospel. It is partially fulfilled in the history of Israel but only finally fulfilled through Christ Jesus. (p. 23)

I wish to push this assertion further to include Adam, that is, when Christ on the cross said that 'it is finished', he meant that the whole of God's plan that was put in operation at creation in the call of Adam, and reintroduced in the call of Abraham, was completed.

At the call of Abraham, mission takes on the redemptive notion; thus, God's mandate for mission to humanity becomes a 'twofold mandate': the cultural mandate and the salvation or redemption mandate. The two mandates stand side by side. The status of humanity after the fall (and as the current status stands) (Gn 6:5) was the cultural mandate and could not be fulfilled without fulfilling the redemption mandate.

God's mandate to Adam, that of creating a God-ward culture, is still in place and needs to be fulfilled. Abraham is now in charge of carrying out God's mandate initially given to 
Adam: the cultural or creation mandate. But unlike Adam who was created when all was good, when there was only one option to every area of human life, Abraham comes at a time when humans have become citizens of another kingdom: the kingdom of darkness. Abraham has to be redeemed from the kingdom of darkness in order for him to be fit to begin calling others to God's kingdom. Thus, Abraham is instructed to come out or to renounce his citizenship of the kingdom of darkness for God's kingdom (Gn 12:1-3). Abraham obeys the instructions and is given the mandate, but this time the mandate takes on another aspect - that of being saved from the kingdom of the devil to the kingdom of God, or change of citizenship from the kingdom of the 'gods of this world, false gods' to the kingdom of Jehovah. The mandate now becomes a twofold mandate ${ }^{6}$ : the cultural and the salvation.

It is this new side of the mandate that brings about a shift in the emphasis from culture to salvation, but there is still the recognition that the goal of God's mandate is the creation of a community with a culture that has God at the centre - a God-ward cultured community, a community in God's place, under God's rule, enjoying God's blessings. But according to the environment under which the mandate is given to Abraham, this cannot be done before first restoring or reclaiming the kingdom of God. Thus, in the call of Abraham, God sets in place his plan for restoration.

\section{Gospel mandate in Matthew 28:19-22}

The gospel mandate, commonly referred to as the 'great commission', holds the instructions of Jesus to his disciples before his ascension. They are his final words to the disciples that send them into the world with God's mission. Burnett observes that the 'great commission' is not a single statement found only in Matthew 28. Although Matthew 28 is the most commonly known and the one that is appealed to in most cases, the great commission is found in all of the first five books of the New Testament: Matthew, Mark, Luke, John and the Acts of the Apostles. Each of the statements as found in a particular book adds elements of importance to the total commission (Burnett 1996:134).

6.At the call of Adam, we see God setting up the pattern in the Garden of Eden. At this point, there was harmony between God and humans, between man and woman and between the whole created orders. God pronounces the newly created world as very good (Gn 1:31). The goodness that is referred to here is the potential goodness, very good ( $\mathrm{Gn} 1: 31)$. The goodness that is referred to here is the potential goodness,
that is, it needed to be natured and developed to realise its full goodness. Adam and that is, it needed to be natured and developed to realise its full goodness. Adam and
Eve, representing humanity, were set apart for this task of populating and civilising the earth, thereby developing a God-ward culture in the new and cultureless world. the earth, thereby developing a God-ward culture in the new and cultureless world.
Adam and Eve failed to live up to God's mandate. Through their disobedience, they set humanity on a course of creating a Godless culture. At the call of Abraham, the world had developed a Godless culture, a culture that sought for independence from God, a culture that doubted the trustworthiness of God and a culture with a serous moral lapse. In the call of Abraham, God begins his plan of restoration by bringing back his creation into fellowship with himself and with one another, and back to the pattern of Eden. To do this, two areas needed to be addressed. The first area involved, firstly, redeeming people from the kingdom of darkness to the kingdom of light, from being disobedient children of God to obedient children of God, and gathering of communities that are set on the course of faith, obedience and loyalty. Secondly, area involved creating in these communities a culture that and loyalty. Secondly, area involved creating in these communities a culture that acknowledges God as the source and final purpose, the creation of a God-ward culture. This comes out clearly in Jesus' mandate to the disciples: 'Go therefore and make disciples of all nations, baptising them .... (Mt 28:19). This is the first area of concern, and is creating communities of the faithful and teaching them to observ all that I have commanded you' (Mt 28.20). This is the second area of concern, and is creating a God-ward culture in the gathered communities. Addressing these two areas of concern is what is referred to as 'the twofold mandate'.
The mandate as given to the disciples is still the salvation or redemption mandate, but the emphasis has shifted to the gospel, the good news. It has become gospel in the sense that from the call of Abraham to the ministry of Jesus, the salvation promised in Genesis 3:15, that of the offspring of the woman crushing the head of the serpent, has finally come in Jesus. When Jesus gave the mandate to the disciples, it was given with the understanding that Jesus, the 'third Adam', had done it all. As Jesus declared on the cross: 'it is finished' (Jn 19:28-30). Jesus by his life, death, resurrection and ascension has secured the tree of life that was prohibited and protected in the garden of Eden (Gn 3:22-24). This is the good news; it is the gospel to be proclaimed and those who embrace this good news are to be baptised as a sign of being restored back to being God's people. As God's people, they are to be taught to live as Jesus lived: the life of faith, obedience and loyalty. In this way, a God-ward cultured community is created.

God's mandate to humankind through Adam, Abraham and Jesus was that of the creation or the development of a community with a God-ward culture, a community ruled by human beings but under the direction of God and for the glory of God. This mandate still remains as God's primary mandate to humankind and God still expects us to carry out this mandate with gratitude in obedience, faith and loyalty. It is worth noting that the great commission is not the first commission nor is it the only one. It has its roots in the cultural mandate and it is the redefined edition of the salvation mandate as given to Abraham.

\section{Relationship between the cultural mandate and the gospel mandate}

How are the two mandates related? We have noted that mission is the creation of a God-ward cultured community. Thus, the two mandates are concerned with the process of how the God-ward cultured community is to be created. With this understanding, the mandates have their roots in God's command to Adam as the representative of the human race to 'be fruitful and multiply and fill the earth' (Gn 1:28). This command is reaffirmed with Noah and his sons in Genesis 9:1. The command is in a way renewed in the call of Abraham (Gn 12:2) and is redefined in the word of the great commission as the mandate to the disciples. However, the mandate is one and is about populating and civilising the earth and creating a God-ward cultured community or communities.

In the cultural mandate, God established a new and good pattern way of life for his kingdom. The whole creation was under God's rule and enjoyed God's blessing. All was good (Gn 1:31). The good that is talked of here is not the good of a final product but potential goodness with room to be developed further. For example, humans were created with the potential to live forever, but only if they did not eat the fruit of the tree of the knowledge of good and evil: 'You may freely eat of every tree of the garden but of the tree of the knowledge of good and evil you shall die' (Gn 2:16). 
When Adam and Eve were created, they were called into a brand new environment. All was new and it was the beginning of all things. God made no other creature in his own image, and being made in the image of God carries with it responsibility (Gn 1:26-27). This responsibility is the purpose for being called into being. Adam and Eve had a purpose in living. They were to glorify God by delighting in him as they exercised dominion over creation. They were also to be fruitful and multiply thereby creating a community with a God-ward culture. In this new environment, the command to 'be fruitful and multiply and fill the earth' could not be fulfilled in any other way but through procreation.

Adam failed to live up to God's call of developing the goodness that God had established and the God-ward culture environment. Contrary to God's mandate, Adam and Eve by their choice set humanity on the course that is opposed to God. They chose to rebel against their creator and in doing so they rejected being the bearers of God's image. They desired to be equal to God: 'You will not die. For God knows that when you eat of it your eyes will be opened, and you will be like God, knowing good and evil' (Gn 3:4). They chose to die and brought about the bad news, thereby setting on the table another option and another side of the coin to every aspect of human life. They introduced the kingdom of darkness in contrast to God's kingdom which is the kingdom of light. As John observes:

God is light and in him is no darkness at all. If we say we have fellowship with him while we walk in darkness, we lie and do not live according to the truth; but if we walk in the light as he is in the light, we have fellowship with one another. (1 Jn 1:5-7)

At the call of Abraham which marks the beginning of the salvation mandate, the world is populated with citizens of the kingdom of darkness, and so the opening words of the command are: 'leave' or 'come out ... and I will make you great nation ...' (Gn 12:1-2). Here, also the command to be 'fruitful and multiply' is to be fulfilled mainly by procreation, but there is room for those who are not biologically born in the family of the kingdom to come in. Their coming in is by personal choice. It is here that the concept of the centripetal model of mission takes its roots.

In the gospel mandate, before the fall, there was no other side of the coin; thus, Adam was not told to love his wife because at that time not loving was not an option. All existed under or in God's love. We cannot talk of the good news of the kingdom because at that time there was only one kingdom: the kingdom of God (Roberts 2004:32-33). The term good news came into use at a later stage in the salvation history. It is a term used by the generation of the third Adam, Jesus. At this stage, there were others offering their so-called good news and Christian good news came with the good news of Jesus as the best option. At this stage, the world continued to be populated by citizens of darkness. Although the chosen people of God, Israel, had failed to live up to the mandate given to Abraham, there still remained the faithful remnants, and out of these came the Messiah through whom the church, as the new Israel, is called.

The church therefore is called to be a community with a God-ward culture and to be a community of faith, obedience and loyalty. To them, the command to be 'fruitful and multiply' is given and the command comes in the words of the great commission: 'Go therefore and make disciples of all nations ...' (Mt 28:19). Here, the command is redefined and is to be fulfilled through personal conversion. There is a shift as the emphasis is no longer on procreation and no longer biological children but rather on spiritual children. It is here that the centrifugal model of mission has its roots.

The two mandates, cultural and salvation or gospel, have one primary goal: the creation of communities that tell the story of who God is as set in the Garden of Eden, God's original goal for his kingdom and God's pattern for the kingdom. As Roberts (2004:32-33) says: 'God's people in God's place, under God's rule, enjoying God's blessing'. The mandates therefore are one mandate given at different times in God's creation history, under different environments but with the purpose of fulfilling one goal.

\section{Conclusion}

The traditional understanding of mission has always carried with it the idea of the geographical expansion of the Christian faith. This involves the planting of the church and the conversion of non-Christians to the Christian faith. This understanding leads to the division of the world and life itself into two spheres: the Christian world and non-Christian world; the Christian culture and nonChristian culture; Christian names and non-Christian names. It is from this understanding that the concept of Christendom drew its strength for dominance over cultures that were not the cultures of the developed world. Unlike the concept of Christendom, the concept of a God-ward culture accepts and acknowledges culture as a gift from God, potentially given for the well-being and identity of every community. It also acknowledges that every culture is potentially good and that there can be no community without culture. Thus, no one particular world, culture or name should be declared or regarded as the Christian world, culture or name.

In setting up the Garden of Eden, God demonstrates how he wishes his world to be. The Garden of Eden is a perfect portrait of what he intended his world to be: a world where all things are in order, a world where there is harmony between God and his creation, and harmony and peace among all of God's creatures. The conversation between the serpent and the woman shows us that there used to be fellowship among God's creatures. They all lived in a friendly environment as 'neighbours'. In short, by creating the Garden of Eden, God set up his kingdom; God's creatures, living in God's place, under God's rule and control, enjoying God's blessing and fellowship. 
Adam and Eve were put in the garden to maintain and develop an organised system of life that acknowledges God as the source and final purpose of creation. This organised system of life or way of life has to do with beliefs, customs, social systems, artistic taste, language, juridical conception, governance and so on. It is this organised way of life that is herein referred to as a 'God-ward culture'. When Adam and Eve were called into being, the world was new with no culture and their task was to develop a culture in a cultureless world - a culture based on the pattern as set by God in the Garden of Eden. They were to multiply and fill the earth with the way of life as set by God, which is a life of faith, obedience and loyalty. However, Adam and Eve failed to live up to their God-given mandate.

At the call of Abraham, the world was populated with disobedient people and only the obedient children were in a position to fulfil the mandate. Obedience is cardinal to fulfilling God's mandate and failure to obey means failure to fulfil the mandate. The task at the call of Abraham became twofold. The first task was to redeem people from the kingdom of darkness to the kingdom of light and from being disobedient children of God to obedient children of God. Once this was done came the task of creating a God-ward cultured community through teaching. Abraham lived up to God's call as he lived the life of faith, obedience and loyalty (Gen. 22).

It has been noted that the cultural mandate, the salvation mandate and the gospel mandate are one and the same, except that in accordance with some development in creation history and according to differences in generations, it takes on a difference in emphasis. The failure of Adam to fulfil the cultural mandate because of his disobedience leads to the mandate to the second phase when it takes on another aspect - that of salvation or restoration. The failure of Israel to live up to the mandate given to Abraham leads the mandate into the third and final phase of the creation history, in which the mandate is redefined and takes on the Good News aspect. But the primary goal still remains the creation of a God-ward cultured community or communities and this is the mandate of the church.

Mission has more to do with the creation of a God-ward culture than the mere crossing of geographical or cultural boundaries. It means the total way of life that tells the story of who God is, a way of life that praises and glorifies God and a way of life that enables each creature to live out its place as assigned by God. In doing so, each creature will fulfil its role in the created order. In this way, the whole creation will be able to praise and glorify God, as was set in the Garden of Eden. As the Psalmist observes, the glory of the Lord will endure forever, and then the Lord will rejoice in his work (Ps 104:31). The mandate that God gave to Adam and Eve (Gn 1:28) as representatives of the human race was not withdrawn rather, it still stands. Thus, developing a God-ward culture is the reason human beings exist; it is our God-given mission.

\section{Acknowledgements Competing interests}

The authors declare that they have no financial or personal relationships that may have inappropriately influenced them in writing this article.

\section{Authors' contributions}

D.G.K. wrote the article under the missiological guidance of S.T.K.

\section{Ethical considerations}

This article followed all ethical standards for research without direct contact with human or animal subjects.

\section{Funding information}

This research received no specific grant from any funding agency in the public, commercial or not-for-profit sectors.

\section{Data availability statement}

Data sharing is not applicable to this article as no new data were created or analysed in this study.

\section{Disclaimer}

The views and opinions expressed in this article are those of the authors and do not necessarily reflect the official policy or position of any affiliated agency of the authors.

\section{References}

Anderson, G.H., 1982, Witnessing to the Kingdom: Melbourne and beyond, SCM Press LTD, London.

Ashford, B.R., 2011, Theology and practice of mission: God, the church and the nations, B\&H, Nashville, TN.

Bartholomew, G.G. \& Goheen, M.W., 2014, The drama of scripture: Finding our place in the biblical story, Barker Academic, Grand Rapids, MI.

Bosch, D.J., 1982, Witness to the world: The Christian mission in theological perspective, Marshall, London.

Bowen, R., 2007, So I send you: A study guide to mission, SPCK, London.

Burnett, D.G., 1996, The healing of the nations: The biblical basis of the mission of God, Carlisle, Paternoster.

Church of England Archbishops' Committee of Inquiry, 1918, The evangelistic work of the church: Being the report of the Archbishops' Third Committee of Inquiry, SPCK, London.

De Young, K. \& Gilbert, G., 2011, What is the mission of the church: Making sense of social justice, Shalom and the Great Commission, Crossway, Wheaton, IL.

Ferguson, S.B. \& Wright, D.F., 1988, New dictionary of theology, Inter-Varsity Press, Leicester.

Fubara-Manuel, B.F., 2007, In the Missio Dei: Reflections on the being and calling in the Sovereign mission of God, Presba, Calabar.

Glasser, A.F., 2003, Announcing the Kingdom: The story of God's mission in the bible, Baker Academic, Grand Rapids, MI.

Goheen, M.W., 2014, Introducing Christian mission today: Scripture, history and issues, InterVarsity Press, Downers Grove, IL.

Hillerbrand, H.J., 2007, The division of Christendom Christianity in the sixteenth century, Westminster John Knox, London.

Kimeria, C., 2017, Colonial name: Taking back my African name as a Kenyan Woman, viewed 23 June 2018, from https://qz.com/.../colonial-name-taking-back-myafrican-name-as-a-kenyan-woman.

Kösternberger, A.J. \& O'Brien, P.T., 2001, Salvation to the ends of the earth: A biblical theology of mission, VarsityPress, Downers Grove, IL.

McKay, J., 1994, The way of the spirit: Times of refreshing, Kingdom Faith Ministries, Horsham. 
Peters, G.W., 1972, A biblical theology of missions, Moody, Chicago, IL.

Roberts, V., 2002, God's big picture, tracing the story-line of the Bible, InterVarsity Press, Leicester.

Roberts, V., 2004, God's big picture: Tracing the storyline of the bible, InterVarsity Press, Leicester.

Stott, R.W.J., 1975, Christian mission in the modern world, InterVarsity Press, Downers Grove, IL.
Taylor, S.J., 2015, How to read the bible (without switching off your brain), SPCK, London. Tennent, T.C., 2010, Invitation to world mission: A Trinitarian missiology for the twenty-first century, Kregel, Grand Rapids, MI.

Wright, H.J.C., 2010, The mission of God's people: A biblical theology of the church's mission, Zondervan, Grand Rapids, MI.

Yoder, J.H., 2014, Theology of mission: A believers church perspective, InterVarsity Press, Downers Grove, IL 